University of Nebraska - Lincoln

DigitalCommons@University of Nebraska - Lincoln

September 2005

\title{
The Effects of Light Exposure and Heat-Aging on Selected Quilting Products Containing Adhesives
}

Janet Evenson

University of Nebraska-Lincoln

Patricia Cox Crews

University of Nebraska-Lincoln, pcrews@unl.edu

Follow this and additional works at: https://digitalcommons.unl.edu/iqscresources

Part of the Social and Cultural Anthropology Commons

Evenson, Janet and Crews, Patricia Cox, "The Effects of Light Exposure and Heat-Aging on Selected Quilting Products Containing Adhesives" (2005). Resources from the IQM. 3.

https://digitalcommons.unl.edu/iqscresources/3

This Article is brought to you for free and open access by the International Quilt Museum at DigitalCommons@University of Nebraska - Lincoln. It has been accepted for inclusion in Resources from the IQM by an authorized administrator of DigitalCommons@University of Nebraska - Lincoln. 


\title{
THE EFFECTS OF LIGHT EXPOSURE AND HEAT-AGING ON SELECTED QUILTING PRODUCTS CONTAINING ADHESIVES
}

\author{
Janet Evenson and Patricia Cox Crews
}

\begin{abstract}
No published data concerning the long-term performance of adhesive-containing commercial products manufactured specifically for the quilt market are available to quiltmakers. Consequently, they cannot make informed choices. The purpose of this study was to carry out accelerated light- and heat-aging tests on selected quilt-basting sprays, fusible webs, and fusible battings to determine whether these products contribute to quilt discoloration or degradation over time. Selected products were exposed to 40 and 80 AATCC fading units of light exposure or 6 and 36 hours of heat-aging. Following light exposure or heat-aging, changes in color, strength, and stiffness were measured. Results of this research show that fusible battings are an acceptable commercial product for quilts intended as heirlooms or for museum collections. On the other hand, all quilt-basting sprays except one were associated with significant yellowing or strength losses following both shorter and longer periods of heat-aging and light exposure. Selected fusible webs are acceptable for quilts intended to last a lifetime (less than 100 years) but are not recommended for quilts intended as heirlooms or art quilts offered for sale to collectors or museums.
\end{abstract}

TITRE-Les résultats de tests de vieillissement accéléré à la lumière et à la chaleur sur divers produits à base d'adhésifs utilisés dans la création des courtepointes. RÉSUMÉ-Il n'existe aucune source publiée contenant des données sur la performance à long terme de produits commerciaux à base d'adhésifs qui sont utilisés par les artistes confectionnant des courtepointes. Il leur est donc difficile de faire des choix éclairés par rapport à ces produits. Le but de cette étude était de réaliser des tests de vieillissement accéléré à la lumière et à la chaleur sur une sélection de fixatifs d'appointage, ainsi que sur certaines voiles et bourres thermofusibles, afin de déterminer si ces produits contribuent à la détérioration des courtepointes ou à l'altération de leurs couleurs à la lumière. Un certain nombre de produits furent testés en les exposant à 40 et 80 unités d'altération à la lumière ou à 6 et 36 heures de chaleur en suivant les normes de vieillissement accéléré établies par l'AATCC
(American Association of Textile Chemists and Colorists - Association américaine des chimistes et coloristes pour les textiles). Les différences de couleurs, de résistance et de rigidité des tissus après vieillissement furent ensuite mesurées. Les résultats de cette étude démontrent que les bourres thermofusibles commerciales passent les tests de vieillissement et donc peuvent être recommandées dans la confection de courtepointes de collection ou dans les applications muséales. Par contre, à une exception près, tous les fixatifs d'appointage sont associés à un jaunissement substantiel ou à une perte de résistance des tissus suivant le vieillissement à la lumière ou à la chaleur, de courte ou de longue durée. Certaines voiles thermofusibles seraient acceptables si elles sont utilisées dans des courtepointes visant à durer moins de cent ans, mais ne peuvent être recommandées pour des oeuvres plus permanentes comme des objets de famille destinés à passer d'une génération à l'autre, ou des oeuvres de collections ou de musées.

TÍTULO-Os efeitos do envelhecimento causado por luz e calor sobre alcochoados artesanais selecionados que usam produtos contendo adesivos. RESUMO-Não há dados publicados disponíveis para os artesãos de alcochoados no que se refere ao comportamento, a longo prazo, de produtos comerciais contendo adesivos, manufaturados especificamente para o mercado de alcochoados artesanais. Conseqüentemente, eles não podem fazer escolhas fundamentadas. $O$ propósito deste estudo foi realizar testes de envelhecimento através da ação da luz e do calor em selecionados sprays, entretelas e estofamentos usados durante o alinhavo, para determinar se esses produtos contribuem para a descoloração ou degradação do acolchoado artesanal através do tempo. Produtos selecionados foram expostos à ação de luz a 40 e 80 AATCC unidades de descoloração ou 6 e 36 horas de ação de calor. Após a exposição à luz ou ação do calor, foram medidas as mudanças na cor, resistência e firmeza. Os resultados dessa pesquisa mostram que os estofamentos de alinhavo são um produto comercial aceitável para acolchoados que se pretende conservar como relíquias de família ou para coleções de museus. Por outro lado, todos os 


\section{JANET EVENSON AND PATRICIA COX CREWS}

sprays usados durante o alinhavo, com exceção de um, foram associados a significante amarelecimento ou perda de resistência depois de curtos ou longos períodos de ação do calor e exposição à luz. As entretelas de alinhavo selecionadas são aceitáveis para acolchoados que se pretende que durem uma vida (menos de 100 anos), mas não são recomendados para acolchoados artesanais que se pretende conservar como relíquias de família ou acolchoados de arte para venda a colecionadores ou museus.

TITULO-Efectos del evejecimiento por luz y por calor en algunos productos que contienen adhesivos para la fabricacion de colchas hechas a mano. RESUMEN-No hay datos publicados sobre el comportamiento a largo plazo de los productos comerciales que contienen adhesivos, fabricados especialmente para el mercado a la disposición de los fabricantes de colchas hechas a mano. Por consiguiente ellos no pueden tomar decisiónes sustentadas en información. El proposito de este estudio fue llevar a cabo pruebas de envejecimiento acelerado con exposición a la luz $\mathrm{y}$ al calor en algunos adhesivos en forma de aspersion para adhesion temporal de las colchas (quilt-basting sprays), redes adhesivas termoplásticas (fusible webs) y guatas termoplásticas (fusible batting), para deteminar si estos productos contribuyen a la aparición de manchas o a la degradación de las colchas a traves del tiempo. Los productos seleccionados fueron expuestos a 40 y 80 unidades AATCC de desvanecimiento por medio de luz o a 6 y 36 horas de envejecimiento por calor. Luego de este periodo de exposición, los cambios en color, en resistencia al rasgado y en rigidez fueron medidos. Los resultados de esta investigación muestran que las guatas termoplasticas son un producto comercial aceptable para la fabricacion de colchas que han sido hechas como un tesoro de familia o que van a formar parte de una colección de museo. Por otra parte, todos los adhesivos en forma de aspersión para adhesión temporal de las colchas, despues de la exposicion a periodos cortos y largos de luz y de calor (con una sola excepción) estuvieron asociados a un amarillamiento significativo $y$ a perdida de resistencia al rasgado. Algunas redes adhesivas termoplasticas son aceptables para el uso en colchas que deben durar una vida (menos de 100 años), pero no se recomiendan para ser utilizadas en colchas que serán un tesoro de familia o colchas artisticas que serán vendidas a coleccionistas o a museos.

\section{INTRODUCTION}

A quiltmaker's choice of materials-including fabric, batting, thread, and other componentsinfluences the life span of the object. When components prematurely yellow, stiffen, or weaken with age, the degradation is disappointing, and sometimes devastating, for individual quiltmakers and their families, as well as for serious collectors or museum curators who may spend thousands of dollars on classic antique or art quilts for their collections.

Conservators and conservation scientists (Down 1984, 1986; Horie 1987; Keyserlingk 1990; Down et al. 1996; Timar-Balazsy and Eastop 1998; Kronthal et al. 2003) have evaluated archival-quality adhesives and identified ones acceptable for use in conservation treatments. Unfortunately, published results concerning the long-term performance of adhesive-containing commercial products manufactured for the quilt market are not readily available to quiltmakers and home sewers or to discerning collectors and curators. Consequently, they cannot make informed choices. Textile scientists and conservators are, however, aware of these commercially available products and have expressed concerns about them. The conservation science literature is filled with reports about the deleterious effects of adhesives on paper and textiles (Himmelstein and Appelbaum 1977; Finch 1980; Blum 1982; Feller and Encke 1982; Smith 1983; Masschelein-Kleiner and Bergiers 1984; Feller 1994; Down et al. 1996; Timar-Balazsy and Eastop 1998).

The purpose of this study was to carry out lightand heat-aging tests on three types of adhesives used in quilting. Products tested included three quilt basting sprays: Sullivans, Sulky KK2000, and 505 Spray and Fix; three fusible webs: Stitch Witchery, Pellon WonderUnder, and HeatnBond; and three fusible battings: June Tailor Low Loft (polyester), Stearns Mountain Mist White Gold (cotton), and Hobbs Heirloom (80\% cotton $/ 20 \%$ polyester blend). The goal was to determine whether the selected adhesive-containing commercial products contribute to discoloration or promote degradation of fabrics over time. 


\section{THE EFFECTS OF LIGHT EXPOSURE AND HEAT-AGING ON SELECTED QUILTING PRODUCTS CONTAINING ADHESIVES}

\author{
2. MATERIALS AND \\ EXPERIMENTAL METHODS
}

\subsection{MATERIALS}

Quilt-basting sprays have been available for some time and are used to temporarily bond the top and backing layers to the batting in lieu of pin or hand basting. The adhesives in these sprays are dissolved in a solvent; when the solvent evaporates, it leaves behind the solid adhesive that bonds fabric to batting with pressure. The chemical constitution of these quiltbasting sprays is proprietary. Most brands proclaim their adhesives to be colorless, nontoxic, nonstaining, and acid free, and to have little or no odor.

Sulky brand claims "bonding will disappear in 2-5 days." Sullivans' labeling information asserts its adhesive spray "has a non-permanent bond which is repositionable," and upon washing it will be "completely removed." The Spray and Fix label claims that it is "colorless, stainless" and "acid free." While the adhesive bond may dissipate over time, the adhesive compound will not disappear. In addition, the adhesives may be water-soluble as claimed during the first few months after application, but it is unlikely that they will remain water-soluble indefinitely. Therefore, unless the quilt is laundered soon after completion, it seems likely that the adhesive spray will eventually cause discoloration of the fabrics.

Fusible webs have been available for more than 30 years and are used for appliqué techniques as well as for "basting" fabric to batting. The adhesives in fusible webs activate when heat is applied, thereby bonding fabric to batting. Stitch Witchery, developed and trademarked in 1969 , is a polyamide polymer, which patent records describe as a "thermally activatable adhesive in net form" (Stitch Witchery 1969). Pellon's Wonder-Under is another polyamide polymer commercially available since 1986 (WonderUnder 1987). Polyamide polymers are known to be particularly susceptible to photo-oxidation from ultraviolet light and heat (Smith 1983). HeatnBond, available since 1989 , is a mixture of polyvinyl alcohol (PVOH) polymers, resin, and a tackifier, according to the company (Scott 2002). $\mathrm{PVOH}$ in its pure form has been used for conservation treatments for many years. However, it is known to stiffen over time (Timar-Balazsy and Eastop 1998).
Fusible battings, coated with a heat-activated resin, "baste" the fabric to the batting when ironed in place and are another option for eliminating traditional basting. Fusible battings have been around since 2001 (Repp and Yogerst 2001). As with the quilt-basting sprays, the adhesive resins used in fusible battings are proprietary.

\subsection{EXPERIMENTAL METHODS}

The resistance of temporary-bond adhesive sprays, fusible webs, and fusible battings to light and heat was evaluated in this study. Fabric assemblies were constructed using the three categories of adhesive-containing products and cotton muslin (Testfabrics Style $400 \mathrm{M}$ ) as the top layer, and cotton batting (Hobbs Heirloom bleached) as the bottom layer. The two layers were bonded together with each of the adhesive sprays or fusible webs. Fusible batting fabric assemblies differed from the others in that, because adhesive is applied to both surfaces of the batting, the fusible batting was sandwiched between two layers of cotton fabric.

Two sets of controls were prepared without adhesive products. One set (control C) contained a top layer of cotton muslin stitched to cotton batting (Hobbs Heirloom bleached). This control was used for the adhesive sprays and the fusible webs. The other set contained a layer of nonfusible batting sandwiched between two layers of cotton muslin and stitched together to provide a control for the fusible battings. Control-C2 contained cotton batting (Hobbs Heirloom bleached), and control-P2 contained polyester batting (Stearns Mountain Mist). Three replicate sets of materials were prepared and evaluated.

\subsection{ADHESIVES ANALYSIS}

The University of Nebraska's Department of Chemistry Research Instrumentation Facility was enlisted to identify the chemical classification of the adhesives used in the products being tested. Fourier transform infrared (FTIR) spectroscopy was employed to determine the chemical classification of the adhesive sprays. A Nicolet Avatar 360 instrument with a Spectra-Tech horizontal attenuated total reflectance (HATR) accessory was used for the analysis. Specimens were prepared by spraying each commercial adhesive product directly onto a zinc selenide ATR plate and allowing the adhesive 


\section{JANET EVENSON AND PATRICIA COX CREWS}

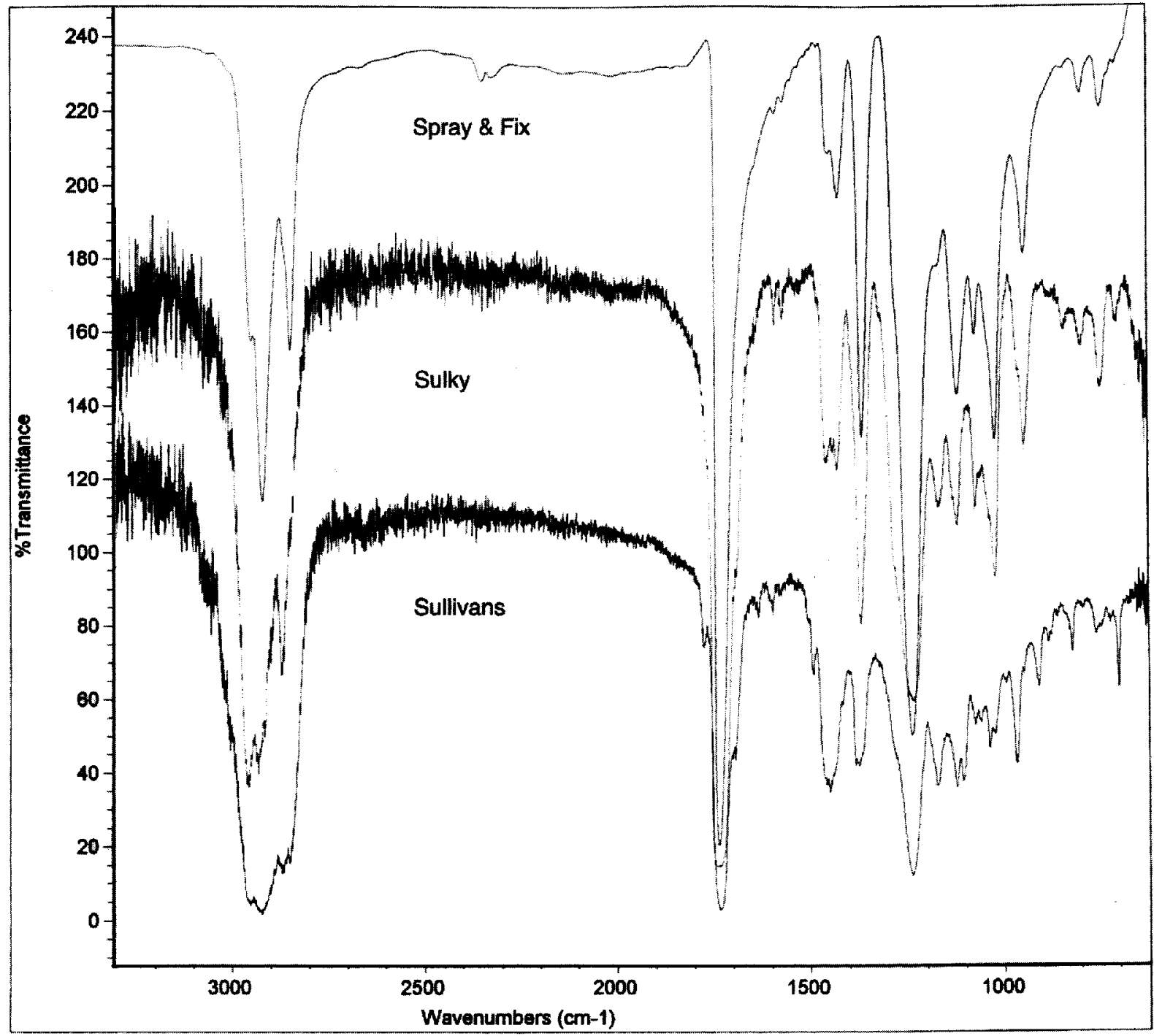

Fig. 1. FTIR spectra of quilt-basting sprays

compound to dry and the propellants to evaporate. The FTIR spectra of the three quilt-basting sprays are shown in figure 1 . The spectra of the three adhesive sprays were compared to a reference database (Hummel Polymer Library) included in the Nicolet Omnic software. The Spray and Fix matched the reference spectrum for PVAC at the 95\% confidence level; the results of the FTIR analysis of Sulky and Sullivans quilt-basting sprays were inconclusive, though there were similarities in the spectra of all three products. Because the Sulky and Sullivans quilt-basting sprays appear to be mixtures, no exact match was found.

Archival-quality PVAC is one of the most light resistant of the solvent-based adhesives. In addition, it does not appreciably cross-link or degrade in air and in some formulations remains soluble in an alcoholwater mixture after more than 30 to 40 years (Horie 1987). It has been used in conservation treatments since the 1930s (Himmelstein and Appelbaum 1977; Smith 1983; Horie 1987). Nevertheless, it has a number of negative properties; it is "inflammable, toxic, foul-smelling and expensive since you ... throw over half the bulk away by evaporation" (Smith 1983, 49). In addition, PVAC becomes brittle as it ages, owing primarily to loss of solvent (Smith 1983).

Composition of the thermoplastic polymers constituting the fusible webs was corroborated using fiber solubility tests rather than infrared or nuclear magnetic resonance (NMR). American Society for 


\section{THE EFFECTS OF LIGHT EXPOSURE AND HEAT-AGING ON SELECTED QUILTING PRODUCTS CONTAINING ADHESIVES}

Testing and Materials (ASTM 2001a) test methods were followed. Stitch Witchery and Wonder-Under were identified as polyamide products by the manufacturers. Polyamides have been used in conservation treatments since the 1950s (Horie 1987). They are soluble in a mixture of water and alcohol, but become less soluble as they age (TimarBalazsy and Eastop 1998) and are especially susceptible to photodegradation (Horie 1987). The manufacturer of HeatnBond described it as a web containing PVOH. PVOH also has been used for conservation treatments since the 1950 s as "a consolidant for textiles and as a heat-seal adhesive for paper" (Horie 1987, 99). The polymer is water soluble. Pure PVOH has been shown to be relatively resistant to ultraviolet and oxygen-aging; however, it may become insoluble after light-aging (Horie 1987).

Identification of the adhesives used in the fusible battings proved more challenging because they were applied in such a thin layer. FTIR spectroscopy (Nicolet Avatar 360 instrument) and proton nuclear magnetic resonance using a Bruker Avance $500 \mathrm{MHz}$ instrument were employed in an attempt to determine the chemical classification of the adhesives used in the fusible battings. The results were inconclusive. Given the wide range of thermosetting resins available and constraints on resources, it was not possible to conclusively identify the chemical class of the adhesives. The adhesive compound incorporated in the June Tailor batting looked visually different from the adhesives used in the Hobbs Heirloom and Mountain Mist fusible battings. The June Tailor adhesive appeared as fine, golden-colored strands throughout the batting. By contrast, the adhesives applied to the Hobbs and Mountain Mist fusible battings were white and were applied in a thin, fairly uniform layer across the surface. We speculate that acrylic resins may have been used in the Mountain Mist and Hobbs battings. Acrylic polymers are increasingly being selected for a variety of applications in the coatings industry because of their improved flexibility compared to polyvinyl acetate emulsions (Lombardi and Gasper 2001). Selected acrylic resins are used in thermosetting adhesives and are known to be extremely resistant to degradation by heat and light (Horie 1987; Lombardi and Gasper 2001). In addition, the newer low-temperature curing types of acrylic adhesives can be designed to have activation temperatures anywhere between room temperature and $90^{\circ} \mathrm{C}$ (Lombardi and Gasper 2001).

\subsection{LIGHT EXPOSURE AND HEAT- AGING}

To determine whether quilting materials containing adhesives would yellow, weaken, or stiffen over time, specimens cut from the fabric assemblies were exposed to heat or light.

Light exposure tests were conducted according to American Association of Textile Chemists and Colorists Procedures (AATCC 2001a). An Atlas Ci65A Xenon Weather-o-meter with soda lime filter was used to simulate sunlight through window glass. Specimens were exposed to either 40 or 80 AATCC fading units (AFUs) of light because selected household textiles (e.g., draperies) are expected to withstand 40 AFUs of accelerated xenon light exposure, according to voluntary industry guidelines. Textiles capable of withstanding 80 AFUs of light without fading exceed most voluntary performance specifications.

Heat-aging was conducted according to a protocol described by AATCC (2001b). Specimens were aged in aVWR forced-air oven, model $1350 \mathrm{M}$, at $275 \pm 4^{\circ} \mathrm{F}\left(135 \pm 2^{\circ} \mathrm{C}\right)$ using water to create steam. The specimens were exposed to either 6 or 36 hours of heat-aging because conservation scientists have equated 7 hours of aging at $140^{\circ} \mathrm{C}$ to a life span of approximately 20 years, and 36 hours of aging at $140^{\circ} \mathrm{C}$ to a 100 -year minimum life span (Feller 1994), the expected life span for an heirloom. This AATCC test method was selected as it is a proven protocol for accelerated heat-aging of textiles, and the conditions used in this study were similar to those described by Feller (1994) in aging tests for conservation materials.

\subsection{EVALUATION OF COLOR CHANGE, BREAKING STRENGTH, AND STIFFNESS}

Following light exposure or heat-aging, changes in color, strength, and stiffness were measured. Color change was evaluated using a HunterLab UltraScan XE diffuse $/ 8^{\circ}$ spectrophotometer according to AATCC (2001c) specifications. An illuminant $D 65 / 10^{\circ}$ observer was used to calculate the colorimetric values. Total color change $(\Delta \mathrm{E})$ was calculated using the CIE $1976 L^{\star} a^{\star} b^{\star}$ equation. Three measurements were performed per specimen. Because there were three replicate specimens, the mean color difference 


\section{JANET EVENSON AND PATRICIA COX CREWS}

value for each adhesive product represents an average of nine measurements.

Warp-breaking strength was measured using an MTS Qtest/10 materials testing system according to ASTM (2001b) standards. The 2.5-cm. cut strip option was followed.

Flexural rigidity of the fabric assemblies following light exposure or heat-aging was determined according to the ASTM (2001c) standard cantilever test using a Drape-Flex Stiffness Tester.

Color difference, percent change in breaking strength, and changes in flexural rigidity were assessed by analysis of variance (ANOVA) procedures. When ANOVA procedures showed that an independent variable had a significant effect,
Tukey's post hoc mean comparison tests were performed to ascertain where statistically significant differences in means were located.

\section{RESULTS AND DISCUSSION}

\subsection{ADHESIVE SPRAYS}

Results showed that one adhesive spray yellowed more than the others (table 1). Specimens containing Sullivans adhesive spray yellowed significantly more than the control or other adhesive sprays following both 40 and 80 AFUs of light exposure, as well as

Table 1. Mean Color Difference Values for Adhesive Sprays Following Light Exposure and Heat-Aging

\begin{tabular}{|c|c|c|c|c|}
\hline \multirow[b]{2}{*}{ Adhesive Spray } & \multicolumn{2}{|c|}{ Light } & \multicolumn{2}{|c|}{ Heat } \\
\hline & 40 AFUs & $80 \mathrm{AFUs}$ & 6 hours & 36 hours \\
\hline & \multicolumn{4}{|c|}{ Color Difference $\left(\Delta \mathrm{E}_{\mathrm{CIE} \mathrm{L}^{*} \mathrm{~A}^{*} \mathrm{~B}}\right)$} \\
\hline Control-C & $0.4 \mathrm{~A}$ & $0.5 \mathrm{~A}$ & $4.1 \mathrm{~A}$ & $10.4 \mathrm{~A}$ \\
\hline Spray and Fix & $0.5 \mathrm{~A}$ & $0.6 \mathrm{~A}$ & $4.7 \mathrm{~A}$ & $11.0 \mathrm{~A}$ \\
\hline Sulky & $0.9 \mathrm{~A}$ & $0.9 \mathrm{~A}$ & $5.3 \mathrm{~A}$ & $11.1 \mathrm{~A}$ \\
\hline Sullivans & $9.1 \mathrm{~B}$ & $9.9 \mathrm{~B}$ & $6.0 \mathrm{~A}$ & $14.9 \mathrm{~B}$ \\
\hline Standard error & 0.6 & 0.5 & 0.6 & 1.2 \\
\hline
\end{tabular}

Note: Control-C at 0 AFUs was used as the standard for calculating $\Delta \mathrm{E}$. Means with the same letter are not significantly different at $\mathrm{p} \leq 0.05$.

Table 2. Mean Percent Change in Breaking Strength for Adhesive Sprays Following Light Exposure and Heat-Aging

\begin{tabular}{lcccc}
\hline \multirow{2}{*}{ Adhesive Spray } & \multicolumn{3}{c}{ Light } & \multicolumn{2}{c}{ Heat } \\
\cline { 2 - 6 } & 40 AFUs & \multicolumn{5}{c}{80 AFUs } & 6 hours & 36 hours \\
Breaking Strength (\% Change) & \\
Spray and Fix & $-3 \% \mathrm{~A}$ & $-12 \% \mathrm{~A}$ & $-8 \% \mathrm{~A}$ & $-7 \% \mathrm{~A}$ \\
Sulky & $-35 \% \mathrm{~B}$ & $-38 \% \mathrm{~B}$ & $-32 \% \mathrm{C}$ & $-38 \% \mathrm{~B}$ \\
Sullivans & $-5 \% \mathrm{~A}$ & $-4 \% \mathrm{~A}$ & $+0 \% \mathrm{~B}$ & $-8 \% \mathrm{~A}$ \\
Control-C & $-5 \% \mathrm{~A}$ & $-8 \% \mathrm{~A}$ & $-1 \% \mathrm{AB}$ & $-10 \% \mathrm{~A}$ \\
& & & & \\
Standard error & $4 \%$ & $4 \%$ & $4 \%$ & $4 \%$ \\
\hline
\end{tabular}

Note: Means with the same letter are not significantly different at $\mathbf{p} \leq 0.05$. 


\section{THE EFFECTS OF LIGHT EXPOSURE AND HEAT-AGING ON SELECTED QUILTING PRODUCTS CONTAINING ADHESIVES}

Table 3. Mean Change in Flexural Rigidity for Adhesive Sprays Following Light Exposure and Heat-Aging

\begin{tabular}{lcccc}
\hline & \multicolumn{2}{c}{ Light } & \multicolumn{2}{c}{ Heat } \\
\cline { 2 - 5 } Adhesive Spray & 40 AFUs & \multicolumn{2}{c}{$80 \mathrm{AFUs}$} & \multicolumn{2}{c}{6 hours } & 36 hours \\
& \multicolumn{2}{c}{ Change in Flexural Rigidity $(\mathrm{mg} \cdot \mathrm{cm})$} \\
Spray and Fix & $+200 \mathrm{~B}$ & $+500 \mathrm{~A}$ & $+50 \mathrm{~A}$ & $+700 \mathrm{~B}$ \\
Sulky & $-700 \mathrm{~A}$ & $+300 \mathrm{~A}$ & $+200 \mathrm{~A}$ & $+100 \mathrm{~A}$ \\
Sullivans & $+1200 \mathrm{C}$ & $+800 \mathrm{~A}$ & $+600 \mathrm{~A}$ & $+1100 \mathrm{~B}$ \\
Control-C & $+900 \mathrm{C}$ & $+700 \mathrm{~A}$ & $+500 \mathrm{~A}$ & $+900 \mathrm{~B}$ \\
Standard Error & 200 & 100 & 100 & 100 \\
\hline
\end{tabular}

Notes: $+=$ increase in stiffness.

Means with the same letter are not significantly different at $\mathrm{p} \leq 0.05$.

Table 4. Mean Color Difference Values for Fusible Webs Following Light Exposure and Heat-Aging

\begin{tabular}{lcccc}
\hline \multirow{2}{*}{ Fusible Web } & \multicolumn{2}{c}{ Light } & \multicolumn{2}{c}{ Heat } \\
\cline { 2 - 5 } & $40 \mathrm{AFUs}$ & \multicolumn{1}{c}{$80 \mathrm{AFUs}$} & 6 hours & 36 hours \\
Control-C & $0.4 \mathrm{~A}$ & $0.5 \mathrm{~A}$ & $4.1 \mathrm{~A} \mathrm{~B}$ & $10.4 \mathrm{~A}$ \\
Stitch Witchery & $0.6 \mathrm{~A}$ & $0.9 \mathrm{~B}$ & $5.4 \mathrm{~B}$ & $13.9 \mathrm{~B}$ \\
HeatnBond & $1.2 \mathrm{~B}$ & $1.7 \mathrm{C}$ & $5.9 \mathrm{~B}$ & $23.3 \mathrm{D}$ \\
Wonder-Under & $4.3 \mathrm{C}$ & $4.3 \mathrm{D}$ & $3.2 \mathrm{~A}$ & $18.9 \mathrm{C}$ \\
Standard error & 0.5 & 0.5 & 0.4 & 1.5 \\
\hline
\end{tabular}

Notes: Control-C at 0 AFUs was used as the standard for calculating $\triangle \mathrm{E}$.

Means with the same letter are not significantly different at $\mathrm{p} \leq 0.05$.

following 36 hours of heat aging. On the other hand, Sulky adhesive spray specimens exhibited significantly greater strength losses $(>30 \%$ loss) compared to the control $(\sim 5 \%$ loss $)$ or other adhesive spray specimens following 40 and 80 AFUs of light exposure, as well as following 6 and 36 hours of heat-aging (table 2). Despite significant discoloration associated with Sullivans spray adhesive, it exhibited no more strength loss than the control. Spray and Fix was the only adhesive spray product for which there was no significant difference from the control in terms of yellowing, strength loss, and stiffness.

All the adhesive spray specimens (except Sulky) stiffened following heat-aging and light exposure, but no more than the controls (table 3). Unexpectedly, Sulky spray adhesive specimens exhibited a significant loss of flexural rigidity following 40 AFUs of light exposure. This decrease in stiffness may be due to fiber degradation as reflected in the significant strength losses Sulky specimens exhibited following light exposure. As light exposure lengthened to 80 AFUs, photo-oxidation-induced changes resulted in a stiffening of Sulky specimens, as in all other specimens.

The significant differences observed between adhesive sprays were due to differences in product formulations. Spray and Fix, the PVAC-based adhesive formulation, performed satisfactorily. As previously mentioned, PVAC-based adhesive formulations have been used successfully by conservators for many years. Nevertheless, it must be noted that formulations of commercial products frequently change, and often without notice. 


\section{JANET EVENSON AND PATRICIA COX CREWS}

Furthermore, the product formulation currently is not listed on commercial quilt-basting spray product labels. Therefore, quiltmakers who wish to use an adhesive spray in a quilt they intend to become an heirloom should carefully weigh the calculated risks against the convenience. The most prudent practice would be to avoid using commercial spray adhesives entirely because the adhesive formulation is not identified on product labels at this time. Collectors and curators may wish to avoid acquisition of quilts constructed using an adhesive spray.

\subsection{FUSIBLE WEBS}

In general, the fusible webs exhibited no more yellowing, stiffening, or strength losses than the control following 6 hours of heat-aging or 40 AFUs of light exposure (table 4).This result suggests that fusible webs may perform acceptably in quilts and household textiles intended for a life span of less than 100 years.

On the other hand, following 36 hours of heataging, all the fusible webs exhibited undesirable yellowing or product bleed-through. Wonder-Under. exhibited significantly greater amounts of color change than the control following 80 AFUs of light exposure, but this color change was not yellowing. Instead, Wonder-Under exhibited significant product bleed-through, making the appearance unacceptable. In addition, Wonder-Under exhibited significantly greater stiffening than the control following 36 hours of heat-aging (table 5). HeatnBond-the PVOH adhesive formulation-yellowed significantly more than the others. In addition, HeatnBond exhibited significantly greater strength losses after 36 hours of heat-aging than the control or any other fusible web (table 6).

These findings suggest that fusible webs should

Table 5. Mean Change in Flexural Rigidity for Fusible Webs Following Light Exposure and Heat-Aging

\begin{tabular}{|c|c|c|c|c|}
\hline \multirow{3}{*}{ Fusible Web } & \multicolumn{2}{|c|}{ Light } & \multicolumn{2}{|c|}{ Heat } \\
\hline & 40 AFUs & 80 AFUs & 6 hours & 36 hours \\
\hline & \multicolumn{4}{|c|}{ Change in Flexural Rigidity $(\mathrm{mg} \cdot \mathrm{cm})$} \\
\hline HeatnBond & $+800 \mathrm{~A}$ & $+1100 \mathrm{~B}$ & $+2900 \mathrm{C}$ & $+1200 \mathrm{~B}$ \\
\hline Stitch Witchery & $-400 \mathrm{~A}$ & $+100 \mathrm{~A}$ & $-600 A$ & $+50 \mathrm{~A}$ \\
\hline Wonder-Under & $+400 \mathrm{~A}$ & $+900 \mathrm{AB}$ & $+1700 \mathrm{BC}$ & $+2700 \mathrm{C}$ \\
\hline Control-C & $+900 \mathrm{~A}$ & $+700 \mathrm{AB}$ & $+500 \mathrm{AB}$ & $+900 \mathrm{AB}$ \\
\hline Standard error & 200 & 100 & 400 & 300 \\
\hline
\end{tabular}

Notes: $+=$ increase in stiffness.

Means with the same letter are not significantly different at $\mathrm{p} \leq 0.05$.

Table 6. Mean Percent Change in Breaking Strength for Fusible Webs Following Light Exposure and Heat-Aging

\begin{tabular}{lcccc}
\hline \multirow{2}{*}{ Fusible Web } & \multicolumn{2}{c}{ Light } & \multicolumn{2}{c}{ Heat } \\
\cline { 2 - 5 } & $40 \mathrm{AFUs}$ & \multicolumn{1}{c}{$80 \mathrm{AFUs}$} & 6 hours & 36 hours \\
Control -C & $-5 \% \mathrm{~A}$ & $-8 \% \mathrm{~A}$ & $-1 \% \mathrm{~A}$ & $-10 \% \mathrm{~A}$ \\
HeatnBond & $-0.5 \% \mathrm{~A}$ & $-10 \% \mathrm{~A}$ & $+11 \% \mathrm{~A}$ & $-34 \% \mathrm{~B}$ \\
Stitch Witchery & $+3 \% \mathrm{~A}$ & $-9 \% \mathrm{~A}$ & $+2 \% \mathrm{~A}$ & $-7 \% \mathrm{~A}$ \\
Wonder-Under & $-2 \% \mathrm{~A}$ & $-6 \% \mathrm{~A}$ & $+12 \% \mathrm{~A}$ & $-3 \% \mathrm{~A}$ \\
& & & & \\
Standard error & $1 \%$ & $1 \%$ & $2 \%$ & $4 \%$ \\
\hline
\end{tabular}

Note: Means with the same letter are not significantly different at $\mathrm{p} \leq 0.05$. 
THE EFFECTS OF LIGHT EXPOSURE AND HEAT-AGING ON SELECTED

QUILTING PRODUCTS CONTAINING ADHESIVES

Table 7. Mean Color Difference Values for Fusible Battings Following Light Exposure and Heat-Aging

\begin{tabular}{|c|c|c|c|c|}
\hline \multirow[b]{2}{*}{ Fusible Batting } & \multicolumn{2}{|c|}{ Light } & \multicolumn{2}{|c|}{ Heat } \\
\hline & 40 AFUs & 80 AFUs & 6 hours & 36 hours \\
\hline & \multicolumn{4}{|c|}{ Color Difference $\left(\Delta \mathrm{E}_{\mathrm{CIEL}^{*} \mathrm{~A}^{*} \mathrm{~B}}\right)$} \\
\hline Control-P2, stitched & $2.3 \mathrm{~B}$ & $3.0 \mathrm{C}$ & $4.4 \mathrm{~A}$ & $11.8 \mathrm{~A}$ \\
\hline June Tailor $100 \%$ polyester & $0.8 \mathrm{~A}$ & $1.3 \mathrm{AB}$ & $4.6 \mathrm{~A}$ & $11.2 \mathrm{~A}$ \\
\hline Control-C2, stitched & $0.4 \mathrm{~A}$ & $0.5 \mathrm{~A}$ & $4.1 \mathrm{~A}$ & $10.4 \mathrm{~A}$ \\
\hline Mountain Mist $100 \%$ cotton & $0.7 \mathrm{~A}$ & $1.1 \mathrm{AB}$ & $4.6 \mathrm{~A}$ & $11.0 \mathrm{~A}$ \\
\hline $\begin{array}{l}\text { Hobbs Heirloom } 80 \% \text { cotton/ } \\
20 \% \text { polyester }\end{array}$ & $1.0 \mathrm{~A}$ & $1.4 \mathrm{~B}$ & $5.2 \mathrm{~A}$ & $10.4 \mathrm{~A}$ \\
\hline Standard error & 0.2 & 0.2 & 0.2 & 0.2 \\
\hline
\end{tabular}

Note: Control-C or $\mathrm{P}$ at 0 AFUs was used as the standard for calculating $\Delta \mathrm{E}$.

Means with the same letter are not significantly different at $\mathrm{p} \leq 0.05$.

Table 8. Mean Percent Change in Breaking Strength for Fusible Battings Following Light Exposure and Heat-Aging

\begin{tabular}{lcccc}
\hline \multirow{2}{*}{ Fusible Batting } & \multicolumn{2}{c}{ Light } & \multicolumn{2}{c}{ Heat } \\
\cline { 2 - 5 } & 40 AFUs & 80 AFUs & 6 hours & 36 hours \\
& \multicolumn{4}{c}{ Breaking Strength (\% Change) } \\
Control-P2, stitched & $-20 \% \mathrm{~A}$ & $-11 \% \mathrm{~A}$ & $-9 \% \mathrm{~A}$ & $-8 \% \mathrm{~A}$ \\
June Tailor 100\% polyester & $-8 \% \mathrm{~A}$ & $-9 \% \mathrm{~A}$ & $-8 \% \mathrm{~A}$ & $-14 \% \mathrm{~A}$ \\
Control-C2, stitched & $-11 \% \mathrm{~A}$ & $-8 \% \mathrm{~A}$ & $-9 \% \mathrm{~A}$ & $-21 \% \mathrm{~A}$ \\
Mountain Mist 100\% cotton & $-9 \% \mathrm{~A}$ & $-5 \% \mathrm{~A}$ & $-14 \% \mathrm{~A}$ & $-13 \% \mathrm{~A}$ \\
Hobbs Heirloom 80\% cotton/ & $-5 \% \mathrm{~A}$ & $-11 \% \mathrm{~A}$ & $-4 \% \mathrm{~A}$ & $-8 \% \mathrm{~A}$ \\
20\% polyester & & & & \\
Standard Error & $2 \%$ & $1 \%$ & $1 \%$ & $2 \%$ \\
\hline
\end{tabular}

Note: Means with the same letter are not significantly different at $\mathrm{p} \leq 0.05$.

Table 9. Mean Change in Flexural Rigidity for Fusible Battings Following Light Exposure and Heat-Aging

\begin{tabular}{|c|c|c|c|c|}
\hline \multirow{3}{*}{ Fusible Batting } & \multicolumn{2}{|c|}{ Light } & \multicolumn{2}{|c|}{ Heat } \\
\hline & 40 AFUs & 80 AFUs & 6 hours & 36 hours \\
\hline & \multicolumn{4}{|c|}{ Change in Flexural Rigidity $(\mathrm{mg} \cdot \mathrm{cm})$} \\
\hline Control-P2, stitched & $+1000 \mathrm{~A}$ & $+1800 \mathrm{~A}$ & $+1200 \mathrm{~A}$ & $+1100 \mathrm{~A}$ \\
\hline June Tailor $100 \%$ polyester & $-100 \mathrm{~A}$ & $+700 \mathrm{~A}$ & $+3400 \mathrm{~B}$ & $+2400 \mathrm{~A}$ \\
\hline Control-C2, stitched & $+1000 \mathrm{~A}$ & $+1600 \mathrm{~A}$ & $+900 \mathrm{~A}$ & $+1000 \mathrm{~A}$ \\
\hline Mountain Mist $100 \%$ cotton & $+2100 \mathrm{~A}$ & $+2000 \mathrm{~A}$ & $+1200 \mathrm{~A}$ & $+600 \mathrm{~A}$ \\
\hline $\begin{array}{l}\text { Hobbs Heirloom } 80 \% \text { cotton/ } \\
20 \% \text { polyester }\end{array}$ & $+2600 \mathrm{~A}$ & $+1600 \mathrm{~A}$ & $+2800 \mathrm{AB}$ & $+3000 \mathrm{~A}$ \\
\hline Standard Error & 300 & 200 & 300 & 400 \\
\hline
\end{tabular}

Notes: $+=$ increase in stiffness.

Means with the same letter are not significantly different at $p \leq 0.05$. 


\section{JANET EVENSON AND PATRICIA COX CREWS}

not be incorporated in quilts that makers hope will become heirlooms. Because the two polyamide products (Stitch Witchery and Wonder-Under) behaved very differently from each other, it is also clear that knowing the general chemical class of an adhesive as provided on a product label is insufficient information to make an informed decision.

\subsection{FUSIBLE BATTINGS}

All fusible batting products exhibited more yellowing following heat-aging than following light exposure (table 7). None, however, exhibited more yellowing than the controls. In terms of strength loss and stiffness, none of the fusible batting fabric assemblies were significantly different from controls following $80 \mathrm{AFUs}$ of light or 36 hours of heat-aging (tables 8, 9). When incorporated into fabric assemblies, fusible battings exhibited less color change than fabric assemblies containing adhesive sprays or fusible webs. The adhesives used in the fusible battings proved to be the most resistant to heat and light of any of the products evaluated.

\section{CONCLUSIONS}

Fusible battings appear to be an acceptable commercial adhesive-containing product for quilts intended as heirlooms or for sale to collectors or museums. All the quilt-basting sprays, except Spray and Fix, were associated with significant yellowing or strength losses following both shorter and longer periods of heat-aging and light exposure. Fusible webs, while acceptable for quilts intended to last for a lifetime, could not be recommended for quilts intended to be handed down from generation to generation or for studio art quilts intended for sale to serious collectors or museums.

\section{ACKNOWLEDGMENTS}

We gratefully acknowledge the financial support provided for this research by the International Quilt Association and Quilter's Newsletter Magazine. In addition, this research was supported in part by funds provided through the Hatch Act. It is a contribution of the University of Nebraska Agricultural Research Division, Journal Series 14289.

\section{REFERENCES}

AATCC. 2001a. Colorfastness to light, Option E, 161998. Research Triangle Park, N.C.: American Association of Textile Chemists and Colorists.

AATCC. 2001b. Ageing of sulfur-dyed textiles: Accelerated, alternate oven test, 26-1999. Research Triangle Park, N.C.: American Association of Textile Chemists and Colorists.

AATCC. 2001c. Instrumental color measurement: Evaluation procedure 6. Research Triangle Park, N.C.: American Association of Textile Chemists and Colorists.

ASTM. 2001a. Standard test methods of identification of textile fibers, D276-00a. West Conshohocken, Pa.: American Society for Testing Materials.

ASTM. 2001b. Standard test method of breaking force and elongation of textile fabrics, D5035-95. West Conshohocken, Pa.: American Society for Testing Materials.

ASTM. 2001c. Standard test method of stiffness of fabrics, Option A, D1388-96. West Conshohocken, Pa.:American Society for Testing Materials.

Blum, D. 1982. An evaluation of some uses of synthetic resins in textile conservation. Proceedings of the Symposium on Resins in Conservation, Edinburgh, U.K., May 21-22. Scottish Society for Conservation and Restoration, 81-88.

Down, J. L. 1984. Adhesive testing at the Canadian Conservation Institute, past and future. In Preprints of the Contributions to the Paris Congress. London: International Institute for Conservation of Historic and Artistic Works. 18-21.

Down, J. L. 1986. The yellowing of epoxy resin adhesives: Report on high-intensity light aging. Studies in Conservation 31:159-70.

Down, J. L., M. A. MacDonald, J. Tetreault, and R. S. Williams. 1996. Adhesive testing at the Canadian Conservation Institute:An evaluation of selected poly (vinyl acetate) and acrylic adhesives. Studies in Conservation 41:19-44. 


\section{THE EFFECTS OF LIGHT EXPOSURE AND HEAT-AGING ON SELECTED QUILTING PRODUCTS CONTAINING ADHESIVES}

Feller, R. L. 1994. Accelerated aging: Photochemical and thermal aspects. Ann Arbor, Mich.: Edwards Brothers.

Feller, R. L., and D. B. Encke. 1982. Stages of deterioration: The examples of rubber cement and transparent mending tape. In Science and technology in the service of conservation: Preprints of the contributions to the Washington Congress, ed. N.S. Brommelle and G. Thompson. London: International Institute for Conservation of Historic and Artistic Works. 19-23.

Finch, K. 1980. Changing attitudes-New developments-Full circle. In Conservation and restoration of textiles, ed. F. Pertegato. Milan: Centro Italiano per lo Studio della Storia del Tessuto. 82-86.

Himmelstein, P., and B.Appelbaum. 1977. The use of sprayed polyvinyl acetate resin mixtures in the mounting of textiles. Journal of the American Institute for Conservation 17:37-44.

Horie, C. V. 1987. Materials for conservation: Organic consolidants, adhesives and coatings. London: Butterworths.

Keyserlingk, M. 1990. The use of adhesives in textile conservation. In ICOM Committee for Conservation Preprints. 9th Triennial Meeting, Dresden. Los Angeles: ICOM. 307-12.

Kronthal, L., J. Levinson, C. Dignard, E. Chao, and J. Down. 2003. Beva 371 and its use as an adhesive for skin and leather repairs: Background and a review of treatments. Journal of the American Institute for Conservation $42: 341-62$.

Lombardi, R., and J. Gasper. 2001. Acrylic polymers. In Coatings and technology handbook, ed. D. Satas and A. Tracton. New York: Marcel Dekker. 391-402.

Masschelein-Kleiner, L., and F. Bergiers. 1984. Influence of adhesives on the conservation of textiles. In Preprints of the Contributions to the Paris Congress, ed. N.S. Brommelle, E.M. Pye, P. Smith, and G. Thompson. London: International Institute for Conservation of Historic and Artistic Works. 70-73.

Repp, J., and F. Yogerst. 2001. Fusible batting. U.S. Patent 6,838,398. Assigned to June Tailor Inc., Richfield, WI. Also available at www.uspto.gov/main/ patents.htm.
Scott, B. 2002. Personal communication. Therm O Web Inc., Wheeling, Ill.

Smith, J. A., ed. 1983. Adhesives and coatings. Science for Conservators, Book 3. London: Crafts Council.

Stitch Witchery. 1969. Thermally activatable adhesive in net form. Trademark Serial Number 72319981. Assigned to Stitch Witchery, Stone Mountain, Ga. Also available at www.uspto.gov/trademarks.htm (accessed July 2002).

Timar-Balazsy, A., and D. Eastop. 1998. Chemical principles of textile conservation. London: Butterworths.

Wonder-Under. 1987. Fusible adhesive material for bonding fabrics. U.S. Trademark Serial Number 73670113. Assigned to Wonder-Under, Durham, N.C. Also available at www.uspto.gov/trademarks.htm (accessed June 2003).

\section{SOURCES OF MATERIALS}

505 Spray and Fix

JT Trading

3 Simm Lane

Newtown, Conn. 06470

(203) 270-7744

fax: (203) 270-8746

www.sprayandfix.com

Sulky KK2000

Sulky of America

3113 Broadpoint Dr.

Punta Gorda, Fla. 33983

(800) 874-4115

fax: (941) 743-4634

www.sulky.com

Sullivans Quilt-Basting Spray

Sullivans USA

4341 Middaugh Ave.

Downers Grove, Ill. 60515

(800) 862-8586

www.sullivans.net/usa/default.htm

HeatnBond

Therm O Web

770 Glenn Ave.

Wheeling, Ill. 60090

(800) 323-0799 


\section{JANET EVENSON AND PATRICIA COX CREWS}

(847) $520-5200$

fax: (847) 520-0025

www.thermoweb.com

Stitch Witchery

HTC-Handler Textile Corp.

1717 Lilton Dr.

Stone Mountain, Ga. 30083

(770) 938-7014

Fax: (770) 938-7018

htcann@aol.com

www.htc-handler.com

Wonder-Under

Pellon Consumer Products Division

Freudenberg Nonwovens

3440 Industrial Dr.

Durham, N.C. 27704

(800) 223-5275

fax: (908) 387-0152

www.pellonideas.com

Hobbs Heirloom $80 \%$ Cotton $/ 20 \%$ Polyester Blend Fusible Batting, Hobbs Heirloom Bleached 100\%

\section{Cotton Batting}

Hobbs Bonded Fiber

200 South Commerce Dr.

Waco, Tex.

(254) 741-0040

(800) 433-3357

www.hobbsbondedfibers.com

June Tailor Low Loft Fusible Batting

June Tailor

P.O. Box 208

2861 Highway 175

Richfield, Wisc. 53076

(800) 844-5400

(262) 644-5288

fax: (800) 246-1573, (262) 644-5061

www.junetailor.com/fusablebatting.htm
Mountain Mist White Gold 100\% Cotton Fusible Batting, Mountain Mist Nonfusible 100\% Polyester Batting

Stearns Technical Textiles Company

100 Williams St.

Cincinnati, Ohio 45215

(513) 948-5275

(800) $345-7150$

fax: (513) $948-5281$

www.stearnstextiles.com/mountainmist/welcom

e.htm

Cotton Muslin

Testfabrics, Inc.

P.O. Box 26

West Pittston, Pa. 18643

(570) 603-0432

fax: (570) 603-0433

www.testfabrics.com

JANET EVENSON holds an MS in textile science from the University of Georgia and a $\mathrm{PhD}$ from the University of Nebraska-Lincoln with a specialization in textiles and a minor in museum studies. She is an assistant professor at Western Illinois University, where she teaches textile science courses. Address: 142 Knoblauch Hall, 1 University Circle, Macomb, Ill.61455; j-evenson@wiu.edu

PATRICIA COX CREWS is Willa Cather Professor of Textiles, Department of Textiles, Clothing, and Design, and director of the International Quilt Study Center at the University of Nebraska-Lincoln (UNL). She has more than 20 years of research experience pertaining to the performance properties of textile materials. She teaches care and conservation of textile collections and textile history at UNL.Address: 204 HE Building, University of Nebraska-Lincoln, Lincoln, Neb.68583-0802; pcrews@unl.edu

Received for review on May 1, 2004. Accepted for publication November 8, 2004. 